\title{
The impact of green facades and vegetative cover on the temperature and relative humidity within model buildings
}

Article

Accepted Version

Creative Commons: Attribution-Noncommercial-No Derivative Works 4.0

Thomsit-Ireland, F., Essah, E. A. ORCID:

https://orcid.org/0000-0002-1349-5167, Hadley, P. and Blanuša, T. (2020) The impact of green facades and vegetative cover on the temperature and relative humidity within model buildings. Building and Environment, 181. 107009. ISSN 03601323 doi: https://doi.org/10.1016/j.buildenv.2020.107009 Available at https://centaur.reading.ac.uk/91882/

It is advisable to refer to the publisher's version if you intend to cite from the work. See Guidance on citing.

To link to this article DOI: http://dx.doi.org/10.1016/j.buildenv.2020.107009

Publisher: Elsevier

All outputs in CentAUR are protected by Intellectual Property Rights law, including copyright law. Copyright and IPR is retained by the creators or other copyright holders. Terms and conditions for use of this material are defined in the End User Agreement. 


\section{CentAUR}

Central Archive at the University of Reading

Reading's research outputs online 
The impact of green facades and vegetative cover on the temperature and relative humidity within model buildings

Faye Thomsit-Ireland ${ }^{1}$, Emmanuel A. Essah ${ }^{1}$ and Paul Hadley ${ }^{3}$, Tijana Blanuša ${ }^{2,3,}$ *

${ }^{1}$ School of Built Environment, University of Reading, RG6 6DF, UK

${ }^{2}$ Science Department, Royal Horticultural Society, RHS Garden Wisley, Woking GU23 6QB, UK

${ }^{3}$ School of Agriculture, Policy and Development, University of Reading, RG6 6AS, UK

*corresponding author: tijanablanusa@rhs.org.uk 


\section{Abstract}

Vertical greening solutions such as direct greening are gaining popularity due to their relatively low cost and minimal ground footprint. However, concerns about increases in relative humidity (RH) can reduce implementation.

The impact of several widely-used plant species (Hedera helix, Parthenocissus tricuspidata and Pileostegia viburnoides) on the internal/external temperature and $\mathrm{RH}$ on the south-facing wall of replicated experimental model 'buildings' was studied during summer and winter. All plant species reduced the air temperature internally/externally during the summer daytimes by at least $1{ }^{\circ} \mathrm{C}$ compared to bare 'buildings'. Hedera produced the greatest cooling effect internally and externally, by $7.2{ }^{\circ} \mathrm{C}$ and $5.7{ }^{\circ} \mathrm{C}$ respectively. All plant species reduced daily variation in external $\mathrm{RH}$ and external/internal temperature during summer; Hedera reduced variation most and Pileostegia least. During night-time in both seasons, the temperature behind Hedera foliage typically remained higher, which could reduce the risk of freeze-thaw damage in winter.

The RH was not significantly elevated by vegetation except during warm afternoons in summer and winter. During warm afternoons, the external RH was significantly higher only behind the Hedera foliage compared to the bare 'buildings', $11 \%$ and $3.7 \%$, summer and winter respectively. However, inside all vegetated 'buildings' the RH was at least $11 \%$ higher compared to the bare 'buildings' during summer. Yet, in winter the internal RH was $5.7 \%$ lower in the Hedera-covered compared to the bare 'buildings'. Current building standards would prevent the transfer of external RH in this range internally, as the walls include protective layers such as damp-proof membranes. 


\section{Key words}

Cooling, damp, green walls, insulation, ivy, relative humidity 


\section{Introduction}

Anthropogenically induced global warming is occurring and causing a widespread environmental disruption (Bernstein et al., 2007). Approximately $25 \%$ of global greenhouse gases (GHG) emissions relate to heat and electricity production; reducing the need to heat and to cool buildings will thus reduce emissions (EPA, 2017). Within Britain, approximately $85 \%$ of housing stock is constructed with materials that have twice the thermal conductivity of current standards, hence the materials are less insulating (Hamilton et al., 2013), leading to increased energy use to maintain thermal comfort. External green walls (i.e. vegetative cover on building walls) may form part of an integrated solution to these problems. A wide variety of green walls are in use around modern buildings: from highly engineered structures (living walls systems) to the simpler direct greening, where climbers attach to the structure directly (Perini et al. 2011b).

There are two ways in which green walls may reduce thermal fluctuations around buildings, notably by cooling (primarily via evapotranspiration and shading) and by providing insulation (Cameron et al., 2014, 2015). Cooling from evapotranspiration and shading, however, are typically considered together as they cannot easily be separated. Studies have shown that on hot days, built structures behind foliage are significantly cooler, within and outside of the building, than those left bare (Di and Wang, 1999, Ip et al., 2004, Miller et al., 2007, Ip et al., 2010, Pérez et al., 2011a,b, Cameron et al., 2014, Feitosa and Wilkinson 2018; Vox et al. 2018, Zhang et al. 2019). Additionally, the dominant cooling effect is dependent on the plant variety used in the greening scheme. Parthenocissus grown across windows to provide shade also increased the humidity inside the building by between $5 \%$ and $14 \%$ between July and October (indicating evapotranspiration processes) compared to bare buildings (Miller et al., 2007). The thermal effects detected are, however, affected by building aspect; shading effects are typically more pronounced on the south wall in the northern hemisphere, as there are more solar gains (Cameron et al., 2014). Furthermore, these effects have only occasionally been studied at night or during spring/autumn where the effects were more marginal (Di and Wang, 1999, Cameron et al., 2014). Extrapolation from some green roof studies in hot and humid scenarios also suggests that night-time ventilation (e.g. opening of windows) is required to achieve night timecooling benefit when vegetation is present (Ran and Tang, 2018).

Insulation effects may become more prominent during cooler periods where cooling via evapotranspiration and shading is reduced. During full days in winter, dense Hedera grown round model 'buildings' increased external wall temperatures by between 1.6 and $3{ }^{\circ} \mathrm{C}$, depending on the weather conditions, compared to bare 'buildings' (Cameron et al., 2015). The Hedera-covered model 'buildings' also consumed less energy for heating and emitted less thermal energy than bare model 
'buildings' (Cameron et al., 2015). This is in agreement with another study showing the thermal resistance and insulating effects of Hedera foliage (Ottelé and Perini, 2017), and the general notion that denser green wall canopy density (such as that of Hedera) is linked to better insulation properties (Widiastuti et al., 2018). Furthermore, the daily temperature variation of a wall surface behind Hedera foliage has also been found to be reduced compared to a bare wall surface (Sternberg et al., 2011). Therefore, Hedera may be capable of acting as a multipurpose solution to issues of thermal comfort.

Historically there has been an on-going debate about the extent to which Hedera (ivy) cladding causes damp problems to buildings by preventing evaporation from the facade (Taddyforde et al., 1877, Muckley, 1886), which continues to this day (BRE et al., 1996, Douglas \& Noy, 2011, Sternberg et al., 2010, Ottelé, 2011). According to documents from the American Society of Heating, Refrigerating and Air-Conditioning Engineers ASHRAE Standard 62.1-2013 (ASHRAE, 2013), the internal atmosphere of buildings should be maintained at less than $65 \%$ relative humidity $(\mathrm{RH})$ for ideal air quality and comfort. The World Health Organisation also recommended that RH be limited to less than $75 \%$ in buildings to restrict mould growth, which can have a detrimental effect on human health (WHO, 2009). Additionally, if walls become damp, the thermal conductivity of the walls increases, thus increasing heat losses (Kumaraperumal, 2009). Our recent work (Thomsit-Ireland, 2019) shows however that plant species such as Hedera, along with Parthenocissus and Pileostegia, display relatively low rates of transpiration (i.e. water loss through leaf stomata). The use of such species may thus reduce dampness issues and concerns around the use of vegetation on and around walls.

In situations where the greatest temperature disparity would occur between greened and bare walls the highest RH differences would also occur. This is due to the basic concepts of RH being a function of absolute humidity (the moisture content of the air) and temperature (Green and Perry, 2007). In winter in particular, as the British maritime climate is typified by moderate (rather than sub-zero) ambient temperatures, however, there may be grounds for concern over use of Hedera in this country, in terms of its possible impact of increasing RH in and around buildings.

The primary natural source of moisture for any building envelope (i.e. not due to leaky guttering or a burst pipes) is driving rain ( $D^{\prime}$ Ayala and Aktas, 2016). The building facet primarily impacted by winddriven rain depends on the choice of materials (Kumaraperumal, 2009), location and prevailing winds, therefore varies from city to city (Karagiozis et al., 2003).

Furthermore, Rath et al. (1989) found no difference in the moisture content of exterior plaster and brickwork between Hedera- and Parthenocissus-greened walls versus those left bare. Additionally, 
when walls were covered with Hedera, there was evidence that the temperature and humidity stabilisation provided by the Hedera covering would reduce the risk of frost and salt deterioration [including historic buildings and limestone buildings; Sternberg et al. (2011)].

As a result of client concerns, landscape designers and architects tend to avoid the use of vegetation around buildings (R. Griffin and C. Trickey, personal comment). It is therefore necessary to determine whether Hedera and other species used in direct greening can cause damage to buildings through increased $\mathrm{RH}$ and under which circumstances.

Many studies have investigated the cooling effects of Hedera on the building envelope during summer (Köhler, 1993, Di and Wang, 1999, Cameron et al., 2014, Hoelscher et al., 2016, Ottelé and Perini, 2017) or looked at similar effects resulting from foliage cladding with other species such as Parthenocissus and Wisteria (Hoyano, 1988, Cantuaria, 2000, Ip et al., 2010, Pérez et al., 2011a, Susorova et al., 2013, Hoelscher et al., 2016). There are common issues with a lack of replication, however (Eumorfopoulou and Kontoleon, 2009, Wong et al., 2010, Koyama et al., 2013, Zhang et al., 2013, Feitosa and Wilkinson 2018, Vox et al. 2018), and in those studies with excellent replication; internal temperature and internal RH were not examined or reported (Sternberg et al., 2011, Cameron et al., 2015). A few studies considered winter conditions in structures with Hedera-covering (Sternberg et al., 2011, Cameron et al., 2015, Ottelé and Perini, 2017) or living wall systems - LWS (Kronvall and Rosenlund, 2014, Matheus et al., 2016, Djedjig et al., 2017, Ottelé and Perini, 2017). Very few studies considered alternatives to Hedera (for example, evergreen direct greening such as Pileostegia) in winter or autumn except Perini et al. (2011a) who included Pyracantha as part of mixed planting in an indirect greening option and evergreen plants in a LWS. The original contribution from our study is its robust, replicated design conducted during both summer and winter seasons. We investigated the effects of three different plant species (applied as direct greening) on the internal and external relative humidity and temperatures of model brick 'buildings'), in the context of a temperate climate. The replicated planting design should enable us to assess confidently genuine plant species differences in various environmental scenarios. Experimental set op uses upgraded and extended plots from the previous study on the same site (Cameron et al., 2014, Cameron et al., 2015), where buildings have been mortared and insulated and a range of plant species - with differing structural and functional characteristics - had been expanded.

\section{Methods}

\subsection{Construction and layout of model buildings}


Twelve model 'buildings' were built in the grounds of the glasshouse complex, at the University of Reading, UK (Figure 1). The experiments were conducted between $24^{\text {th }}$ June and $20^{\text {th }}$ July 2015 (summer) and between $14^{\text {th }}$ January and $4^{\text {th }}$ February 2016 (winter). The treatment for each building was applied using a partially randomised design, which allowed the previously established Hedera plants to remain in situ. The layout is shown in Error! Reference source not found.2.

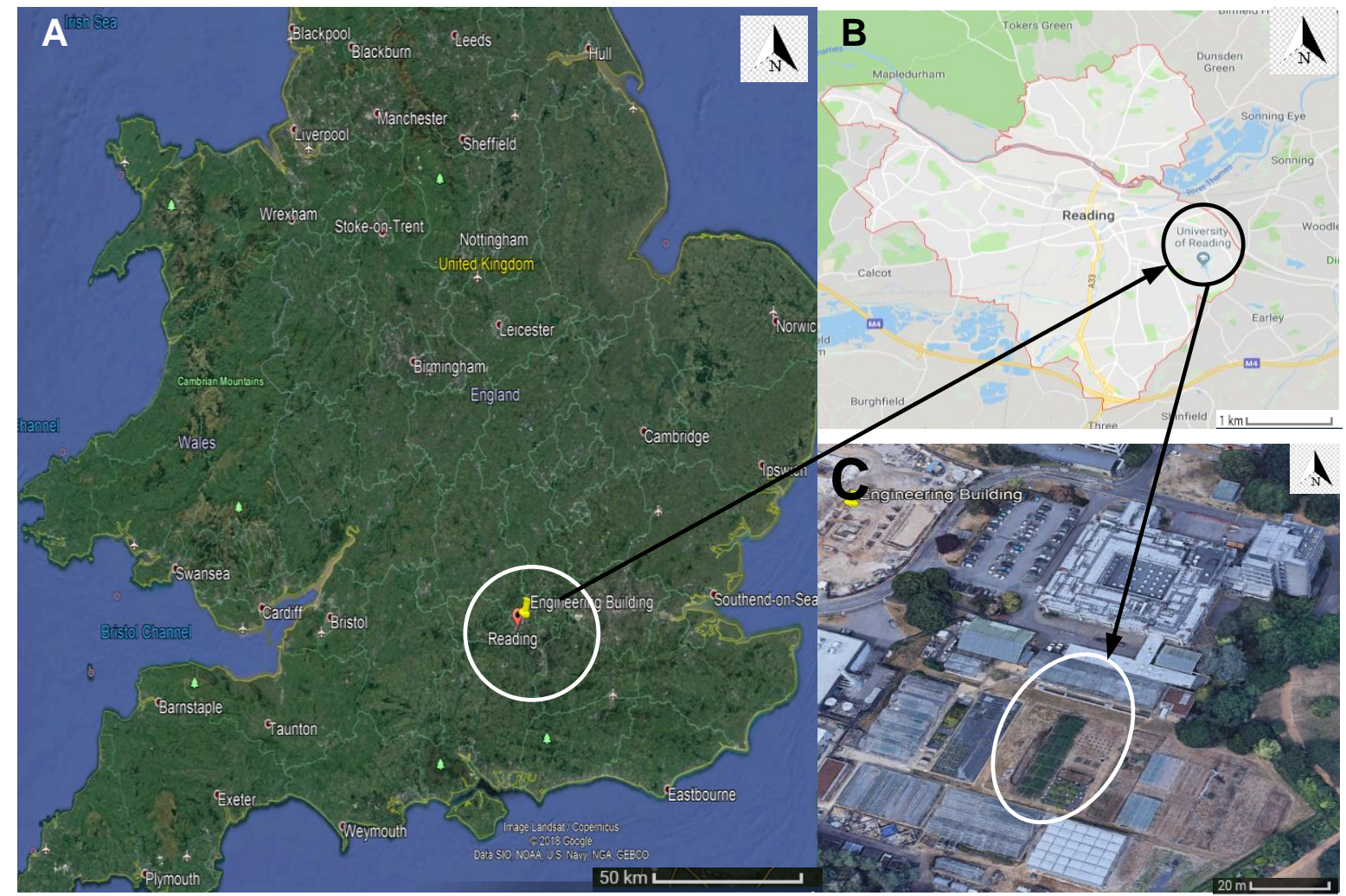

Figure 1: Location of the experimental site in Reading, UK $(A)$ at the University of Reading $(B)$, within the experimental and glasshouses grounds of the School of Agriculture, Policy and Development, view from Google Earth, elevation 68m (C) 

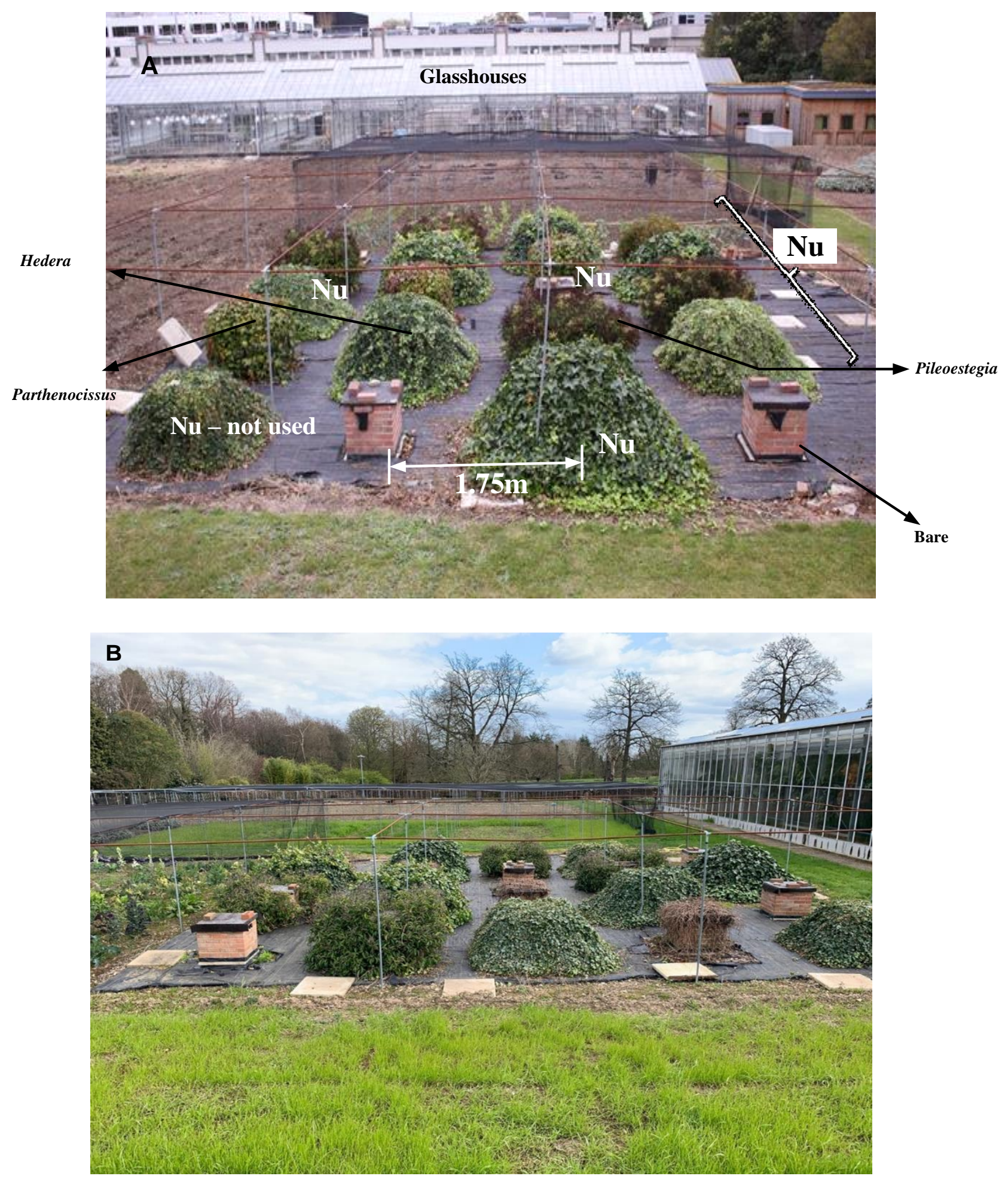

Figure 2. Photographs of the general experimental plot layout with model 'buildings', in the summer ( $A$, image taken from the south) and winter ( $B$, image taken from the west). Three replicates of each of three plant species (Hedera, Parthenocissus and Piloestegia) and three bare buildings were used in this experiment (details on planting are provided in Section 2.2). Winter image is taken from the west side to highlight Parthenocissus (second from right), a deciduous plant which had dropped leaves, thus making it more similar to a bare building than a vegetated one. Pictures of plots were taken in August 2019 and February 2020 (4 years after experiments 
finished) are intended as a visual guide of the plot design, rather than the exact experimental scene (which is described fully in the body of Material and Methods).

The 'buildings' were each made with 64 bricks [standard red clay brick (classified BSEN 771, Class B, $215 \times 103 \times 65 \mathrm{~mm}$; thermal properties: $\mathrm{k}=1.1 \mathrm{Wm}^{-1} \mathrm{~K}^{-1}$, Blockley's Brick Holdings plc., Telford, UK)], arranged in a stretcher bond, with grey concrete slabs forming the base. Dimensions of an individual building, with all components listed below, were $0.6 \mathrm{~m}(\mathrm{~h}) \times 0.5 \mathrm{~m}(\mathrm{w}) \times 0.5 \mathrm{~m}(\mathrm{~d})$. Distance between the buildings was $1.5 \mathrm{~m}(\mathrm{~N}-\mathrm{S})$ and $1.75 \mathrm{~m}(\mathrm{E}-\mathrm{W})$ so the adjacent buildings did not cast a significant shade on one another during the selected experimental periods.

Prior to construction, the concrete slabs and base layer of bricks were dried for two days at $70^{\circ} \mathrm{C}$, to reduce their moisture content. A layer of sand and cement mortar (ratio of 4 sand to 1 cement) was then applied to the weed resistant matting to provide a level surface and a 1200 gauge $(0.3 \mathrm{~mm})$ damp proof membrane (DPM) was laid upon the mortar. An insulated 'roof' was constructed from Metsä Wood oriented strand board (OSB; $600 \times 600 \times 11 \mathrm{~mm}$ ) with $1.3 \mathrm{~mm}$ bitumen shed felt secured with clout roofing nails providing a $50 \mathrm{~mm}$ overhang on the north and south sides and a $100 \mathrm{~mm}$ overhang on the east and west sides ( 3 and Figure 4). Then a $3 \mathrm{~mm}$ thick multi-layer air bubble film insulation with aluminium bonded to both faces 'silvered insulation' was secured over $20 \times 311 \times 18 \mathrm{~mm}$ wood batons, which were fixed to the OSB that formed the roof on the model building, with a $20 \mathrm{~mm}$ overlap onto the brick and an $18 \mathrm{~mm}$ air gap between the OSB and the 'silvered insulation' (Figures 3 and 4). A suspended timber floor was constructed using a $401 \times 311 \times 18 \mathrm{~mm}$ section of marine ply as a base and an equivalent sized piece of 'silvered insulation', which was sandwiched between six batons ( $20 \mathrm{x}$ $311 \times 18 \mathrm{~mm}$ ) and nailed to the 'floor'. This created two $18 \mathrm{~mm}$ air gaps, one above and one below the 'silvered insulation'. The 'floor' was laid above the DPM and was secured in place with weatherproof external silicone. 


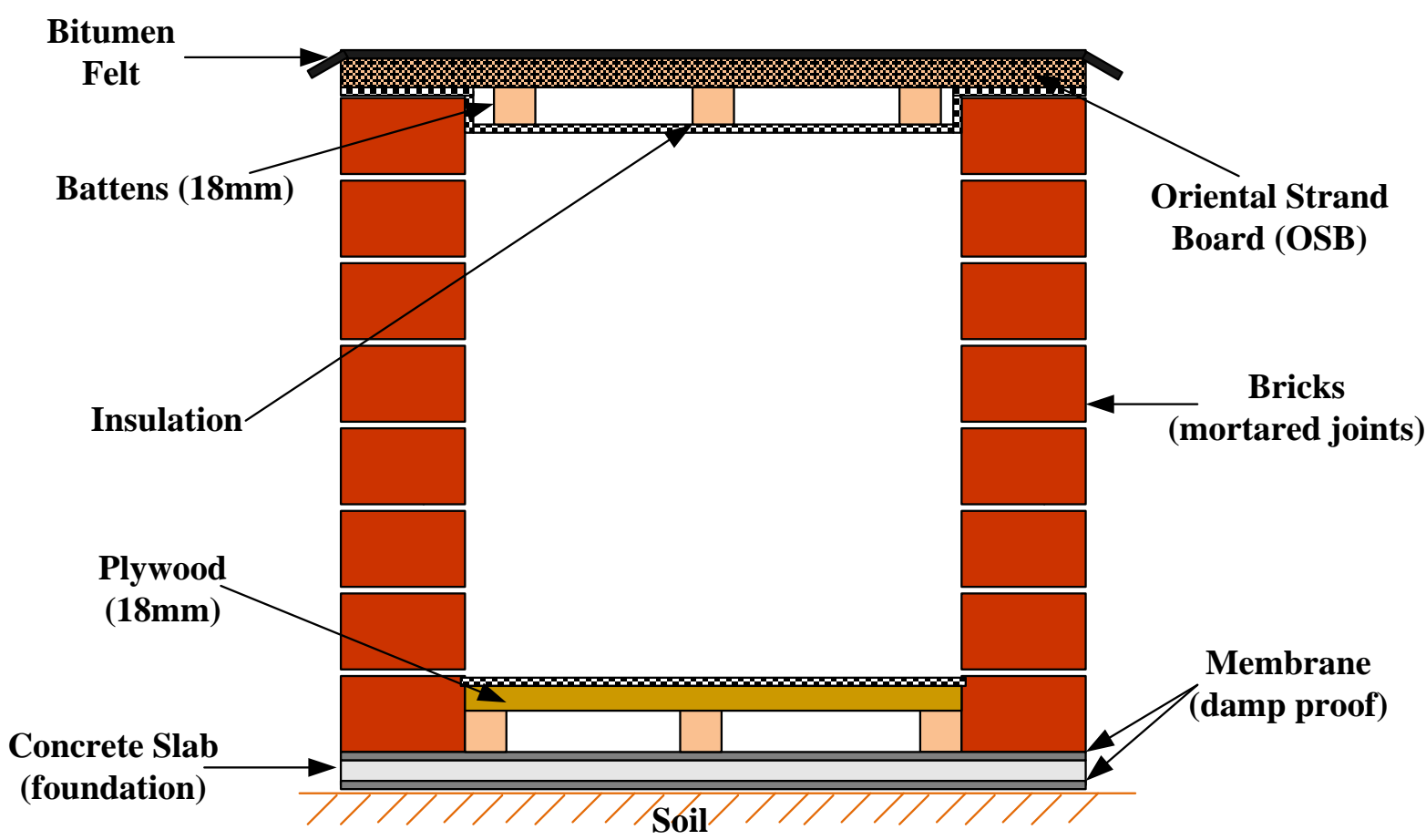

Figure 3 Diagram of model 'building' construction (not to scale). Detailed dimensions are provided in the text.
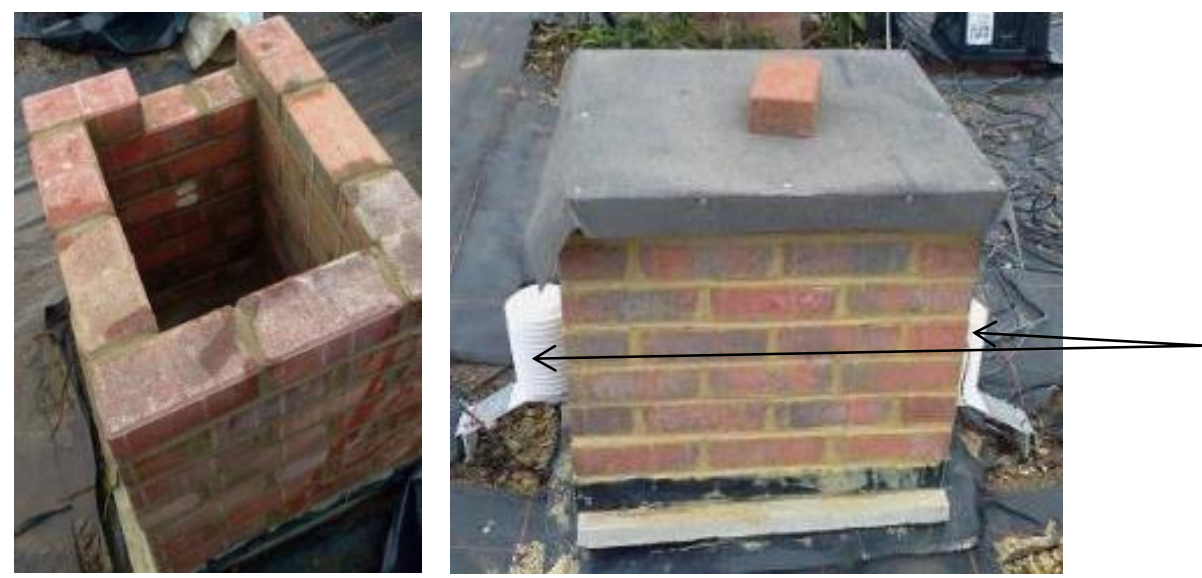

RHT2nl sensors

Figure 4 L-R: Bare model 'building' without roof (left) and with roof and screened RHT2nl sensors in situ (right)

During the winter experiment the model 'buildings' were heated with a thermostatically controlled 75 W aquarium heater Hidom $\mathrm{HT}-2075$, permanently set to $30^{\circ} \mathrm{C}$, using a thermostat on the heater head and submerged - as an immersion heater - within a jumbo size cooking-oil container of $5 \mathrm{~L}$ volume (KTC Sunflower oil) (Figure 5). No distinction was made between thermal contributions of the heater and incoming solar radiation at times. However, as the experimental treatments were well replicated, it was assumed that the overall impact of both factors will be evenly spread between the treatments.

\subsection{Plant material and replication of planted treatments}


Three plant species were used around the model 'buildings': Hedera helix (common ivy), Parthenocissus tricuspidata (Virginia creeper) and Pileostegia viburnoides (climbing hydrangea). Ivyclad buildings consisted of a 50\% $-50 \%$ mix of Hedera helix variety 'Glacier' (supplied by Johnsons of Whixley, Yorkshire, UK) and straight Hedera helix (propagated in house), planted in December 2011, and pruned to the roofline and to $200 \mathrm{~mm}$ depth by the walls in 2014. For the other two species threeyear-old Pileostegia viburnoides, and Parthenocissus tricuspidata 'Veitchii' (obtained from Chiltern Trees and Shrubs, Wallingford, UK and Provender Nurseries Ltd, Swanley, UK, respectively) in 2 L containers and planted at the end of April 2014 were used. Eight plants were installed around each 'building', two per side, spaced between 250 and $300 \mathrm{~mm}$ apart. By the time experiments started all greened buildings were robustly covered by vegetation.

During the experiment the depth of vegetation varied as plants became increasingly established. In July 2015 a visual inspection estimated that the wall coverage was $89 \pm 6 \%$ for Hedera, $99 \pm 1 \%$ for Parthenocissus, and $84 \pm 10 \%$ for Pileostegia (probably due to the nature of its crown development). In January 2016 the plants had similar coverage to summer 2015, apart from the Parthenocissus which is deciduous, so its stems remained but there were no leaves.

During both summer and winter there were four experimental 'treatments': Hedera-, Parthenocissusand Pileostegia-covered buildings, along with bare 'buildings', with three replicates per treatment.

\subsection{Sensors and logging}

The relative humidity $(\mathrm{RH})$ and air temperature were measured $50 \mathrm{~mm}$ from the internal and external south wall of the model 'buildings' to ensure readings were not directly influenced by the facade. Measurements were made continuously every 10 seconds and averaged every 10 minutes, using RHT2nl probes connected to a DL2e data logger (Delta-T Devices Ltd, Cambridge, UK). The RHT2nl probes were screened with radiation screens and positioned $200 \mathrm{~mm}$ above the ground. The $\mathrm{RH}$ sensor was accurate to $\pm 2 \%$ and the temperature sensor was accurate to $\pm 0.1{ }^{\circ} \mathrm{C}$. Additional temperature measurements were made in summer with screened thermistors (type Fenwal UUA32J2, in-house construction), placed $15 \mathrm{~mm}$ from the internal and external walls of the model 'buildings' at approximately $200 \mathrm{~mm}$ from the ground. These were also connected to a DL2e data logger and accurate to $0.2{ }^{\circ} \mathrm{C}$. The sensors are shown in situ for each of the treatments in Figure 6 , and the summer and winter sensor set ups are shown in appendix A. The local ambient weather conditions were monitored by the University of Reading meteorological observatory (UoR MO). During the experimental periods in the summer (June 2015) were $22.1{ }^{\circ} \mathrm{C}$ ( $\mathrm{T}$ max), $12.1^{\circ} \mathrm{C}(\mathrm{T}$ min) and $2.3 \mathrm{~mm}$ (rainfall), and in winter (January 2016): $9.0^{\circ} \mathrm{C}$ (T max), $1.8^{\circ} \mathrm{C}$ (T min) and $1.9 \mathrm{~mm}$ (rainfall). 

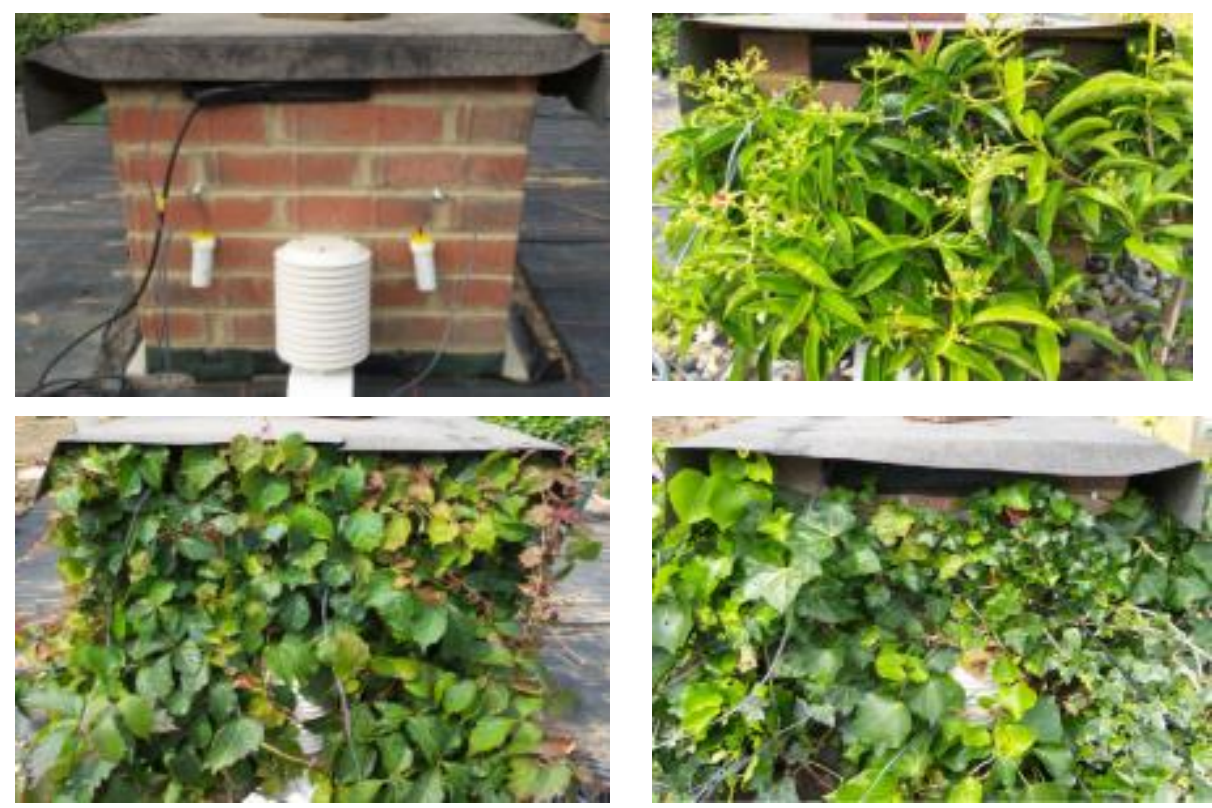

Figure 6 Top left to bottom right: Bare model 'building' and 'buildings' covered with Pileostegia viburnoides, Parthenocissus tricuspidata and Hedera helix, with roof and sensors in situ: set up for summer 2015

\subsection{Selecting time periods for analysis}

The times chosen for analysis were based on the maximum and minimum ambient temperatures, as determined by the UoR MO, during the period of the most stable ('flattest') parts of the diurnal temperature variation. In summer the coldest part of the day typically occurred between 03:00 and 05:00 Greenwich mean time (GMT), while in the winter the coldest time occurred between 05:00 and 07:00 GMT. However, the warmest part of the day typically occurred between 14:00 and 17:00 GMT during both summer and winter. Data was extracted from the data loggers, and then configured for statistical analysis, using a bespoke programme written in $\mathrm{C}++$.

In summer 2015 , the six warmest and five coolest days were analysed. The $29^{\text {th }}, 30^{\text {th }}$ June, and $1^{\text {st }}, 3^{\text {rd }}$, $4^{\text {th }}, 16^{\text {th }}$ July were selected as 'warm' days (where the mean ambient temperature between 14:00 and 17:00 at the UoR MO was $>23^{\circ} \mathrm{C}$ ), and the 'cold' days selected were $28^{\text {th }}$ June and $5^{\text {th }}, 8^{\text {th }}, 12^{\text {th }}, 13^{\text {th }}$ July 2015 (where the mean ambient temperature between 14:00 and 17:00 at the UoR MO was < 19 ${ }^{\circ} \mathrm{C}$. Once days were selected according to the criteria above, both mornings and afternoons, from 03:00-05:00 BST and 14:00-17:00 BST respectively, were analysed.

In winter 2016 the days analysed were:

- 'Cold' days without heaters installed inside the 'buildings': $15^{\text {th }}$ to $17^{\text {th }}$ January 2016 (where the mean ambient temperature from 05:00-07:00 GMT at UoR MO was $<3{ }^{\circ} \mathrm{C}$ ). These represented a baseline for comparison with later results. 
- 'Cold' days with heaters installed inside the 'buildings': $19^{\text {th }}$ to $21^{\text {st }}, 28^{\text {th }}$ January, and $3^{\text {rd }}$ February 2016 (where the mean ambient temperature from 05:00-07:00 GMT at UoR MO was $\leq 3{ }^{\circ} \mathrm{C}$.

- 'Warm' days with heaters installed inside the 'buildings': $24^{\text {th }}, 25^{\text {th }}, 29^{\text {th }}$ January, and $1^{\text {st }}$ February 2016 (where the mean ambient temperature from 05:00-07:00 GMT at UoR MO was $>9^{\circ} \mathrm{C}$.

There were no days during the monitored period that correlated to the 'warm' day specifications when the heaters were not installed.

Once days were selected for analysis according to the criteria above, both mornings and afternoons, from 05:00-07:00 GMT and 14:00-17:00 GMT respectively, were analysed.

\subsection{Statistical Analysis}

The mean was calculated with data from each time period (for example, 14:00-17:00), and all the chosen days in the same scenario (for example, the 'cold' days during summer) which removed any temporal pseudo-replication. Then a one-way analysis of variance (ANOVA) was conducted using GenStat (16th Edition), using a 95\% confidence interval. Variances were checked for homogeneity and values were presented as means with the associated least significant differences of the means (LSD), as well as standard deviation (SD) of the un-averaged data set. One-way ANOVA generates a single $p$ value which relates to the overall analysis, while the use of LSD enables comparisons of the individual means. We have also performed additional, post-hoc analysis, to enable multiple comparisons of the means using Tukey's post-hoc test (in the SPSS statistical package); where it is statistically significant we have reported those Tukey's $p$ values in the text.

\section{Results}

\subsection{External RH during summer 2015}

During 'cold-' and 'warm day' mornings the external RH measured behind the foliage of vegetated 'buildings' was not significantly different from the RH measured next to bare 'buildings' $(p=0.228$, LSD $=7.4$ and $p=0.231, L S D=7.2$ Table 1). Nor was that measured on 'cold day' afternoons, at $9 \%$ higher ( $p=0.06$, LSD 7=.5). There was also, no significant increase in the RH measured behind the foliage of the Pileostegia- and Parthenocissus-covered 'buildings' compared to the bare 'buildings' in either temperature scenario (Tukey's $p=0.364$ and $p=270$ for warm and $p=607$ and $p=366$ for cold).

During 'warm day' afternoons, however, the external RH measured behind Hedera foliage was $11 \%$ higher $(p=0.033, L S D=7.5$, Tukey's $p=0.014)$ than that measured next to bare 'buildings' (Table 1$)$. 
All vegetated treatments significantly reduced the daily variation in the external $\mathrm{RH}$ in all temperature scenarios, compared to that measured next to bare 'buildings'. In both scenarios the Hedera foliage produced the greatest reduction in daily variation compared to bare 'buildings' (Tukey's $p=0.024$ for warm and $p=0.032$ for cold) (Table 1 ).

Table 1 Mean \pm SD 'external' relative humidity (\%) in summer 2015 and the associated LSDs (where differences were statistically significant) with three replicates per treatment, d.f. $=8 *$.

\begin{tabular}{|c|c|c|c|c|c|c|}
\hline Scenario & Cold & Cold & Cold & Warm & Warm & Warm \\
\hline Time & $\begin{array}{l}03: 00- \\
05: 00\end{array}$ & $\begin{array}{l}14.00- \\
17.00\end{array}$ & Difference & $\begin{array}{l}03: 00- \\
05: 00\end{array}$ & $\begin{array}{l}14.00- \\
17.00\end{array}$ & Difference \\
\hline Ambient external RH (\%) & $91 \pm 3$ & $71 \pm 11$ & $20 \pm 10$ & $88 \pm 10$ & $45 \pm 11$ & $43 \pm 13$ \\
\hline Bare & $85 \pm 9$ & $62 \pm 14$ & $23 \pm 11$ & $85 \pm 7$ & $36 \pm 10$ & $48 \pm 14$ \\
\hline Hedera & $84 \pm 8$ & $71 \pm 15$ & $13 \pm 9$ & $84 \pm 4$ & $47 \pm 11$ & $37 \pm 10$ \\
\hline Pileostegia & $85 \pm 8$ & $67 \pm 14$ & $18 \pm 9$ & $84 \pm 6$ & $42 \pm 10$ & $42 \pm 12$ \\
\hline Parthenocissus & $79 \pm 10$ & $62 \pm 15$ & $17 \pm 9$ & $78 \pm 7$ & $37 \pm 12$ & $41 \pm 11$ \\
\hline$p$ value & 0.228 & 0.06 & $<.001$ & 0.231 & 0.033 & 0.008 \\
\hline LSD & 7.4 & 7.5 & 3.0 & 7.2 & 7.5 & 5.5 \\
\hline
\end{tabular}

*'Cold' days were when the mean ambient temperature between 14:00 and 17:00 at the UoR MO was $<19{ }^{\circ} \mathrm{C}$. 'Warm' days were when the mean ambient temperature between 14:00 and 17:00 at the UoR MO was $>23{ }^{\circ} \mathrm{C}$. 'Difference' indicates the difference between the morning and afternoon $\mathrm{RH}$. Numbers in bold indicate that those values are significantly different from others in the same column (ANOVA, $p<0.05$ ).

\subsection{Internal RH during summer 2015}

There was no significant effect of plant treatment on the internal measurements of RH made in the mornings, regardless of whether 'warm' or 'cold' days were considered ( $p=0.085$ and $p=0.06$ 'cold' and 'warm day' mornings respectively; Table 2). This was also true on 'cold day' afternoons ( $p=$ 0.189; Table 2). During the 'warm day' afternoons, however, the RH measured inside Hedera-covered 'buildings' was $17 \%$ higher than that measured inside bare 'buildings' (Tukey's $p<0.001$ ); lesser \%wise, but still statistically significant effects were detected for Pileostegia- (9\%) and Parthenocissuscovered (12\%) 'buildings' (Tukey's $p<0.001$, Table 2).

During 'cold' days the daily variation in internal RH was reduced most in the Hedera-covered 'buildings' compared to bare 'buildings' (Tukey's $p=0.032$ ) (Table 2). Conversely during 'warm' days, daily variation in internal $\mathrm{RH}$ was lowest for bare 'buildings' (5.1\% less than Hedera or Parthenocissus treatments, $6.7 \%$ RH less than Pileostegia; $\mathrm{p}<.001 ;$ Table 2). 
Table 2 Mean \pm SD 'internal' relative humidity (\%) in summer 2015 and the associated LSDs (where differences were statistically significant) with three replicates per treatment, except for Parthenocissus-covered buildings which had two replicates due to sensor malfunction d.f. $=7^{*}$.

\begin{tabular}{lcccccc}
\hline Scenario & Cold & Cold & Cold & Warm & Warm & Warm \\
\hline Time & $\begin{array}{c}03: 00- \\
05: 00\end{array}$ & $\begin{array}{c}14.00- \\
17.00\end{array}$ & Difference & $\begin{array}{c}03: 00- \\
05: 00\end{array}$ & $\begin{array}{c}14.00- \\
17.00\end{array}$ & Difference \\
\hline $\begin{array}{l}\text { Ambient external } \\
\text { RH (\%) }\end{array}$ & $91 \pm 3$ & $71 \pm 11$ & $20 \pm 10$ & $88 \pm 10$ & $45 \pm 11$ & $43 \pm 13$ \\
\hline Bare & $53 \pm 5$ & $63 \pm 5$ & $\mathbf{1 0 \pm 3}$ & $54 \pm 5$ & $\mathbf{5 7 \pm 9}$ & $\mathbf{2 . 4} \pm \mathbf{5 . 4}$ \\
\hline Hedera & $65 \pm 5$ & $71 \pm 4$ & $\mathbf{6} \pm \mathbf{2}$ & $67 \pm 5$ & $\mathbf{7 4 \pm \mathbf { 4 }}$ & $\mathbf{7 . 5} \pm \mathbf{1 . 2}$ \\
\hline Pileostegia & $54 \pm 7$ & $63 \pm 6$ & $9 \pm 3$ & $57 \pm 7$ & $\mathbf{6 6 \pm 6}$ & $\mathbf{9 . 1} \pm \mathbf{3 . 4}$ \\
\hline Parthenocissus & $59 \pm 4$ & $68 \pm 2$ & $9 \pm 3$ & $62 \pm 3$ & $\mathbf{6 9} \pm \mathbf{3}$ & $\mathbf{7 . 6} \pm \mathbf{1 . 9}$ \\
\hline p value & 0.085 & 0.189 & $\mathbf{0 . 0 4}$ & 0.06 & $\mathbf{0 . 0 1 1}$ & $<.001$ \\
\hline & & & & & & 1.59 \\
\hline LSD & 9.8 & 8.8 & 2.7 & 9.3 & 8.6 & \\
\hline
\end{tabular}

*'Cold' days were when the mean ambient temperature between 14:00 and 17:00 at the UoR MO was $<19{ }^{\circ} \mathrm{C}$. 'Warm' days were when the mean ambient temperature between 14:00 and 17:00 at the UoR MO was $>23{ }^{\circ} \mathrm{C}$. 'Difference' indicates the difference between the morning and afternoon $\mathrm{RH}$. Numbers in bold indicate that those values are significantly different from others in the same column (ANOVA, $p<0.05$ ).

\subsection{External temperature during summer 2015}

External temperatures measured during 'cold day' mornings, behind the foliage of both the Hederaand Parthenocissus-covered 'buildings', were significantly ( $p=0.014$; Table 3 , at least $1.2{ }^{\circ} \mathrm{C}$ ) warmer than those measured next to bare 'buildings' (Tukey's $p=0.002$ and 0.003 , respectively for Hedera and Parthenocissus). During the 'warm day' mornings, however, no significant temperature difference was observed between plant species and bare walls $(p=0.071$; Table 3 , Tukey's $p$ values $0.123,0.981$ and 0.566 respectively for Hedera, Piloestegia and Parthenocissus compared to bare walls).

During both 'cold' and 'warm day' afternoons, temperatures measured behind the foliage of the vegetated treatments were significantly cooler than those next to bare 'buildings' $(p<.001)$. While effects were more pronounced on 'warm' days, the greatest cooling effect occurred behind the Hedera foliage $\left(2.2 / 5.7{ }^{\circ} \mathrm{C}\right.$ cooler on 'cold'/'warm' days) followed by Pileostegia (1.4/4.6 ${ }^{\circ} \mathrm{C}$ cooler) then Parthenocissus $\left(1.2 / 3.4{ }^{\circ} \mathrm{C}\right.$ cooler) as compared to bare 'buildings' ( $p<.001$; Tukey's $p$ 0.001, 0.001 and 0.014 respectively for Hedera, Piloestegia and Parthenocissus compared to bare walls on warm summer afternoons, Table 3 ).

During 'cold' and 'warm' days, all the vegetated treatments significantly reduced the daily variation in external temperature around 'building' envelopes, compared to the daily variation measured next to bare 'buildings' ( $<$.001; Table 3 ). In both cases, the greatest stabilisation was produced by Hedera $\left(3.2{ }^{\circ} \mathrm{C}\right.$ less variation on average on 'cold' days, $8.3^{\circ} \mathrm{C}$ less on 'warm' days, Tukey's $\mathrm{p}=0.001$ and $<$ 
0.001 for cold and warm respectively). The effects of other species on external temperature stability, whilst not as great as those produced by Hedera, varied based on the temperature scenario. On 'cold' days, variation was lower behind Parthenocissus than Pileostegia (a reduction of $2.4^{\circ} \mathrm{C}$ vs. $1.7{ }^{\circ} \mathrm{C}$ when compared to bare 'buildings', Tukey's $p=0.023$ and 0.193 for Parthenocissus and Pileostegia respectively), but on 'warm' days Parthenocissus and Pileostegia reduced variation in temperature to a similar extent (Tukey's $p=0.002$ and 0.003 for Parthenocissus and Pileostegia respectively).

Table 3 Mean \pm SD 'external' temperature $\left({ }^{\circ} \mathrm{C}\right.$ ) in summer 2015 and the associated LSDs (where differences were statistically significant) with three replicates per treatment, d.f. $=8 *$.

\begin{tabular}{|c|c|c|c|c|c|c|}
\hline Scenario & Cold & Cold & Cold & Warm & Warm & Warm \\
\hline Time & $\begin{array}{l}\text { 03:00 - } \\
\text { 05:00 }\end{array}$ & $\begin{array}{l}14: 00- \\
17: 00\end{array}$ & Difference & $\begin{array}{l}\text { 03:00 - } \\
\text { 05:00 }\end{array}$ & $\begin{array}{l}14: 00 \text { - } \\
17: 00\end{array}$ & Difference \\
\hline $\begin{array}{l}\text { Ambient external } \\
\text { temperature }\left({ }^{\circ} \mathrm{C}\right)\end{array}$ & $14.0 \pm 1.3$ & $18.7 \pm 0.1$ & $4.7 \pm 1.3$ & $14.4 \pm 3.4$ & $26.1 \pm 3.6$ & $11.7 \pm 4.1$ \\
\hline Bare & $15.0 \pm 0.8$ & $22.2 \pm 2.1$ & $7.1 \pm 2.8$ & $14.7 \pm 2.8$ & $32.6 \pm 3.6$ & $17.9 \pm 4.0$ \\
\hline Hedera & $16.2 \pm 0.9$ & $20.0 \pm 1.5$ & $3.9 \pm 2.0$ & $17.3 \pm 5.4$ & $26.9 \pm 2.8$ & $9.6 \pm 5.2$ \\
\hline Pileostegia & $15.4 \pm 0.8$ & $20.8 \pm 1.6$ & $5.4 \pm 2.1$ & $15.2 \pm 2.7$ & $28.0 \pm 3.4$ & $12.8 \pm 3.7$ \\
\hline Parthenocissus & $16.3 \pm 0.7$ & $21.0 \pm 1.7$ & $4.7 \pm 2.0$ & $16.2 \pm 2.4$ & $29.2 \pm 3.2$ & $13.0 \pm 3.2$ \\
\hline$p$ value & 0.014 & $<.001$ & $<.001$ & 0.071 & $<.001$ & $<.001$ \\
\hline LSD & 0.78 & 0.29 & 0.95 & 2.06 & 1.81 & 2.80 \\
\hline
\end{tabular}

*'Cold' days were when the mean ambient temperature between 14:00 and 17:00 at the UoR MO was $<19^{\circ} \mathrm{C}$. 'Warm' days were when the mean ambient temperature between 14:00 and 17:00 at the UoR MO was $>23^{\circ} \mathrm{C}$. 'Difference' indicates the difference between the afternoon and morning temperatures. Numbers in bold indicate that those values are significantly different from others in the same column (ANOVA, $p<0.05$ ).

\subsection{Internal temperatures during summer 2015}

During the 'cold-' and 'warm day' mornings, there were no significant differences between temperatures measured inside any 'buildings' regardless of whether they had been vegetated or remained bare ( $p=0.438$ and 0.617 respectively for cold and warm mornings). During both 'warm' and 'cold day' afternoon scenarios, however, Hedera-covered 'buildings' displayed a significant reduction in internal temperature compared to bare 'buildings'. During 'cold day' afternoons the temperature measured inside Hedera-covered buildings was $3.1^{\circ} \mathrm{C}$ cooler than the temperature measured inside the bare 'buildings' (Tukey's $p<0.001$ ), and $7.2^{\circ} \mathrm{C}$ cooler on 'warm day' afternoons (Tukey's p < 0.001; Table 4).

During both the 'cold' and 'warm' days the daily variation in internal temperature was significantly reduced in all vegetated treatments compared to the bare 'buildings' $(p<.001 ;$ Table 4$)$. The greatest reduction in daily internal temperature variation occurred inside the Hedera covered buildings $\left(3.4^{\circ} \mathrm{C}\right.$ 
less variable on 'cold' days $/ 7.4^{\circ} \mathrm{C}$ on 'warm' days), followed by the Parthenocissus- $\left(2.8^{\circ} \mathrm{C} / 5.6^{\circ} \mathrm{C}\right)$ and Pileostegia-covered $\left(2.5^{\circ} \mathrm{C} / 5.3^{\circ} \mathrm{C}\right)$ 'buildings' $(\mathrm{p}<.001$; Table 4$)$.

Table 4 Mean \pm SD 'internal' temperature $\left({ }^{\circ} \mathrm{C}\right.$ ) in summer 2015 and the associated LSDs (where differences were statistically significant) with three replicates per treatment, d.f. $=8^{*}$.

\begin{tabular}{|c|c|c|c|c|c|c|}
\hline Scenario & Cold & Cold & Cold & Warm & Warm & Warm \\
\hline Time & $\begin{array}{c}\text { 03:00 - } \\
\text { 05:00 }\end{array}$ & $\begin{array}{c}14: 00- \\
17: 00\end{array}$ & Difference & $\begin{array}{c}\text { 03:00 - } \\
\text { 05:00 }\end{array}$ & $\begin{array}{c}14: 00- \\
17: 00\end{array}$ & Difference \\
\hline $\begin{array}{l}\text { Ambient external } \\
\text { temperature }\left({ }^{\circ} \mathrm{C}\right)\end{array}$ & $14.0 \pm 1.3$ & $18.7 \pm 0.1$ & $4.7 \pm 1.3$ & $14.4 \pm 3.4$ & $26.1 \pm 3.6$ & $11.7 \pm 4.1$ \\
\hline Bare & $18.5 \pm 1.2$ & $22.2 \pm 1.9$ & $4.1 \pm 1.9$ & $18.9 \pm 2.6$ & $31.0 \pm 3.8$ & $13.0 \pm 3.2$ \\
\hline Hedera & $18.6 \pm 1.1$ & $19.1 \pm 0.8$ & $0.7 \pm 0.9$ & $18.9 \pm 2.1$ & $23.8 \pm 2.8$ & $5.6 \pm 2.1$ \\
\hline Pileostegia & $18.5 \pm 1.1$ & $20.0 \pm 1.1$ & $1.6 \pm 1.2$ & $18.9 \pm 2.4$ & $26.1 \pm 3.2$ & $7.7 \pm 2.4$ \\
\hline Parthenocissus & $18.7 \pm 1.1$ & $20.0 \pm 1.0$ & $1.3 \pm 1.0$ & $19.1 \pm 2.3$ & $26.1 \pm 3.3$ & $7.4 \pm 2.6$ \\
\hline$p$ value & 0.438 & $<.001$ & $<.001$ & 0.617 & $<.001$ & $<.001$ \\
\hline LSD & 0.15 & 0.57 & 0.64 & 0.37 & 1.57 & 1.70 \\
\hline
\end{tabular}

'Cold' days were when the mean ambient temperature between 14:00 and 17:00 at the UoR MO was $<19^{\circ} \mathrm{C}$. 'Warm' days were when the mean ambient temperature between 14:00 and 17:00 at the UoR MO was $>23^{\circ} \mathrm{C}$. 'Difference' indicates the difference between the afternoon and morning temperatures. Numbers in bold indicate that those values are significantly different from others in the same column (ANOVA, $p<0.05$ ).

\subsection{External RH during winter 2016}

As Parthenocissus is deciduous (i.e. drops leaves in winter) the RH measurements 'behind' its foliage were understandably very similar to the measurements next to the bare 'buildings'. The only significant increase in RH occurred on 'warm day' afternoons during which heating had been 
implemented. In this situation the RH measured behind the Hedera foliage was higher than all the treatments and 3.7\% higher than that measured by the bare 'buildings' $(p=0.01 ; \mathrm{LSD}=2.23$, Table 5).

Table 5 Mean \pm SD 'external' relative humidity (\%) during winter 2016 and the associated LSDs (where differences were statistically significant), with three replicates per treatment, d.f. $=8^{*}$.

\begin{tabular}{lcccccc}
\hline Scenario & Cold (UH) & Cold (UH) & Cold (H) & Cold (H) & Warm (H) & Warm (H) \\
\hline \multirow{2}{*}{ Time } & $05.00-$ & $14.00-$ & $05.00-$ & $14.00-$ & $05.00-$ & $14.00-$ \\
& 07.00 & 17.00 & 07.00 & 17.00 & 07.00 & 17.00 \\
\hline Ambient external RH (\%) & $92.3 \pm 7.6$ & $81.1 \pm 10.9$ & $91.9 \pm 8.6$ & $62.7 \pm 9.9$ & $86.5 \pm 11.0$ & $81.8 \pm 10.6$ \\
\hline Bare & $90.0 \pm 6.0$ & $80.0 \pm 10.7$ & $88.9 \pm 5.9$ & $65.5 \pm 4.8$ & $88.2 \pm 9.5$ & $81.8 \pm 8.4$ \\
\hline Hedera & $85.3 \pm 4.8$ & $79.7 \pm 10.0$ & $83.6 \pm 5.4$ & $67.6 \pm 5.1$ & $89.9 \pm 8.2$ & $85.5 \pm 8.4$ \\
\hline Parthenocissus & $90.2 \pm 5.7$ & $80.1 \pm 11.2$ & $89.1 \pm 5.8$ & $65.5 \pm 4.8$ & $88.7 \pm 9.7$ & $82.0 \pm 8.8$ \\
\hline Pileostegia & $88.2 \pm 6.6$ & $77.9 \pm 11.0$ & $84.9 \pm 6.0$ & $62.7 \pm 4.8$ & $87.3 \pm 9.8$ & $81.4 \pm 9.0$ \\
\hline p value & 0.147 & 0.364 & 0.102 & 0.075 & 0.291 & $\mathbf{0 . 0 1}$ \\
\hline LSD & 4.83 & 3.01 & 5.38 & 3.55 & 2.91 & 2.23 \\
\hline 'Cold' days Wer
\end{tabular}

'Cold' days were when the mean ambient temperature between 05:00 and 07:00 at the UoR MO was $\leq 3^{\circ} \mathrm{C}$. 'Warm' days were when the mean ambient temperature between 05:00 and 07:00 at the UoR MO was $>9^{\circ} \mathrm{C}$. Unheated $(\mathrm{UH})$, heated $(\mathrm{H})$. Unheated and heated days occurred on different days. Numbers in bold indicate that those values are significantly different from others in the same column (ANOVA, $p<0.05$ ).

\subsection{Internal RH during winter 2016}

The RH measured inside the Parthenocissus and Pileostegia-covered buildings generally similar to that within bare buildings. The RH measured inside the Hedera-covered 'buildings' during the 'warm' days with heating was borderline significantly lower than that measured for any of the other treatments $(p=0.054, L S D=4.28$, Table $)$. 
Table 6 Mean \pm SD 'internal' relative humidity (\%) during winter 2016 and the associated LSDs (where differences were statistically significant), with three replicates per treatment, d.f. $=8^{*}$.

\begin{tabular}{lcccccc}
\hline Scenario & Cold (UH) & Cold (UH) & Cold (H) & Cold (H) & Warm (H) & Warm (H) \\
\hline Time & $\begin{array}{c}05.00- \\
07.00\end{array}$ & $\begin{array}{c}14.00- \\
17.00\end{array}$ & $\begin{array}{c}05.00- \\
07.00\end{array}$ & $\begin{array}{c}14.00- \\
17.00\end{array}$ & $\begin{array}{c}05.00- \\
07.00\end{array}$ & $\begin{array}{c}14.00- \\
17.00\end{array}$ \\
\hline $\begin{array}{l}\text { Ambient } \\
\text { external RH (\%) }\end{array}$ & $92.3 \pm 7.6$ & $81.1 \pm 10.9$ & $91.9 \pm 8.6$ & $62.7 \pm 9.9$ & $86.5 \pm 11.0$ & $81.8 \pm 10.6$ \\
\hline Bare & $94.5 \pm 3.3$ & $96.7 \pm 2.7$ & $83.3 \pm 6.3$ & $89.0 \pm 6.8$ & $90.6 \pm 7.1$ & $\mathbf{9 2 . 8 \pm 6 . 8}$ \\
\hline Hedera & $86.6 \pm 2.9$ & $88.6 \pm 2.6$ & $77.9 \pm 4.9$ & $80.7 \pm 4.1$ & $85.3 \pm 5.0$ & $\mathbf{8 7 . 1} \pm 4.9$ \\
\hline Parthenocissus & $92.1 \pm 2.3$ & $95.9 \pm 2.8$ & $81.4 \pm 5.1$ & $86.2 \pm 8.5$ & $91.0 \pm 6.2$ & $93.5 \pm 5.7$ \\
\hline Pileostegia & $90.0 \pm 3.9$ & $94.2 \pm 4.5$ & $79.2 \pm 3.2$ & $84.9 \pm 4.9$ & $89.6 \pm 5.0$ & $92.4 \pm 5.0$ \\
\hline p value & 0.115 & 0.083 & 0.159 & 0.091 & 0.054 & $\mathbf{0 . 0 4 1}$ \\
\hline LSD & 6.65 & 6.59 & 5.17 & 6.41 & 4.28 & 4.54 \\
\hline
\end{tabular}

*'Cold' days were when the mean ambient temperature between 05:00 and 07:00 at the UoR MO was $\leq 3^{\circ} \mathrm{C}$. 'Warm' days were when the mean ambient temperature between 05:00 and 07:00 at the UoR MO was $>9{ }^{\circ} \mathrm{C}$. Unheated $(\mathrm{UH})$, heated $(\mathrm{H})$. Unheated and heated days occurred on different days. Numbers in bold indicate that those values are significantly different from others in the same column (ANOVA, $p<0.05$ ).

\subsection{External wall temperature during winter 2016}

While differences in external wall temperatures between bare buildings and those covered in vegetation were generally small and not statistically significant, there is an indication that during the 'cold day' mornings, temperatures measured behind Hedera foliage were warmer than those measured for any other treatment; $0.4{ }^{\circ} \mathrm{C}$ (for unheated buildings) and $1{ }^{\circ} \mathrm{C}$ (for heated buildings compared to the bare 'buildings'. The temperatures measured behind the foliage of the Parthenocissus and Pileostegia-covered 'buildings' were not significantly different to the temperatures measured by the bare 'buildings' in any scenario. 
Table 7 Mean \pm SD 'external' temperature $\left({ }^{\circ} \mathrm{C}\right)$ during winter 2016 and the associated LSDs, with three replicates per treatment, d.f. $=8^{*}$.

\begin{tabular}{lcccccc}
\hline Scenario & Cold (UH) & Cold $(\mathrm{UH})$ & Cold $(\mathbf{H})$ & Cold $(\mathbf{H})$ & Warm $(\mathrm{H})$ & Warm $(\mathrm{H})$ \\
\hline Time & $\begin{array}{c}05.00- \\
07.00\end{array}$ & $\begin{array}{c}14.00- \\
17.00\end{array}$ & $\begin{array}{c}05.00- \\
07.00\end{array}$ & $\begin{array}{c}14.00- \\
17.00\end{array}$ & $\begin{array}{c}05.00- \\
07.00\end{array}$ & $\begin{array}{c}14.00- \\
17.00\end{array}$ \\
\hline $\begin{array}{l}\text { Ambient external } \\
\text { temperature }\left({ }^{\circ} \mathrm{C}\right)\end{array}$ & $0.5 \pm 1.0$ & $3.5 \pm 0.3$ & $-0.8 \pm 3.7$ & $6.0 \pm 2.6$ & $10.8 \pm 1.0$ & $12.7 \pm 0.8$ \\
\hline Bare & $0.6 \pm 0.6$ & $3.6 \pm 0.5$ & $-0.4 \pm 2.5$ & $5.9 \pm 2.7$ & $10.3 \pm 1.1$ & $12.8 \pm 0.7$ \\
\hline Hedera & $1.0 \pm 0.2$ & $3.4 \pm 0.5$ & $0.6 \pm 2.1$ & $5.5 \pm 2.5$ & $9.9 \pm 1.0$ & $12.0 \pm 0.6$ \\
\hline Parthenocissus & $0.5 \pm 0.6$ & $3.5 \pm 0.5$ & $-0.5 \pm 2.4$ & $5.7 \pm 2.9$ & $10.2 \pm 1.1$ & $12.7 \pm 0.7$ \\
\hline Pileostegia & $0.7 \pm 0.5$ & $3.5 \pm 0.5$ & $-0.1 \pm 2.3$ & $5.9 \pm 2.8$ & $10.3 \pm 1.0$ & $12.7 \pm 0.7$ \\
\hline p value & 0.694 & 0.041 & 0.562 & 0.979 & 0.694 & 0.044 \\
\hline LSD & 0.18 & 0.15 & 0.41 & 0.26 & 0.12 & 0.14 \\
\hline
\end{tabular}

*'Cold' days were when the mean ambient temperature between 05:00 and 07:00 at the UoR MO was $\leq 3^{\circ} \mathrm{C}$. 'Warm' days were when the mean ambient temperature between 05:00 and 07:00 at the UoR MO was $>9^{\circ} \mathrm{C}$. Unheated $(\mathrm{UH})$, heated $(\mathrm{H})$. Unheated and heated days occurred on different days. Numbers in bold indicate that those values are significantly different from others in the same column (ANOVA, $p<0.05$ ).

\subsection{Internal temperature during winter 2016}

During 'cold day' mornings, temperatures measured inside the unheated Hedera- and Pileostegiacovered 'buildings' were warmer ( 1.3 and $0.8{ }^{\circ} \mathrm{C}$ respectively) than those measured inside the bare 'buildings' ( $p=<.001$, Tukey's $p<0.001$ and 0.003 for Hedera and Piloestegia, respectively). Once heaters were installed, temperatures measured inside Hedera- and Pileostegia-covered 'buildings' increased to 2.2 and $0.9^{\circ} \mathrm{C}$ respectively, warmer than those measured inside bare 'buildings' $(p<.001)$. There were no significant differences between the temperatures measured inside the bare 'buildings' and any other treatment during either afternoons or 'warm day' mornings with heating (Table 8). 
Table 8 Mean \pm SD 'internal' $\left({ }^{\circ} \mathrm{C}\right.$ ) temperature during winter 2016 and the associated LSDs (where differences were statistically significant), with three replicates per treatment, d.f. $=8^{*}$.

\begin{tabular}{lcccccc}
\hline Scenario & Cold (UH) & Cold $(\mathbf{U H})$ & Cold $(\mathbf{H})$ & Cold $(\mathbf{H})$ & Warm $(\mathbf{H})$ & Warm $(\mathbf{H})$ \\
\hline Time & $\begin{array}{c}05.00- \\
07.00\end{array}$ & $\begin{array}{c}14.00- \\
17.00\end{array}$ & $\begin{array}{c}05.00- \\
07.00\end{array}$ & $\begin{array}{c}14.00- \\
17.00\end{array}$ & $\begin{array}{c}05.00- \\
07.00\end{array}$ & $\begin{array}{c}14.00- \\
17.00\end{array}$ \\
\hline $\begin{array}{l}\text { Ambient external } \\
\text { temperature }\left({ }^{\circ} \mathbf{C}\right)\end{array}$ & $0.5 \pm 1.0$ & $3.5 \pm 0.3$ & $-0.8 \pm 3.7$ & $6.0 \pm 2.6$ & $10.8 \pm 1.0$ & $12.7 \pm 0.8$ \\
\hline Bare & $\mathbf{1 . 0 \pm 0 . 6}$ & $3.2 \pm 1.0$ & $\mathbf{3 . 9} \pm \mathbf{2 . 6}$ & $8.0 \pm 3.0$ & $11.4 \pm 2.0$ & $13.6 \pm 2.5$ \\
\hline Hedera & $\mathbf{2 . 3} \pm \mathbf{0 . 2}$ & $3.1 \pm 0.7$ & $\mathbf{6 . 1} \pm \mathbf{2 . 2}$ & $8.0 \pm 2.2$ & $11.5 \pm 1.7$ & $12.7 \pm 2.1$ \\
\hline Parthenocissus & $\mathbf{1 . 0 \pm 0 . 5}$ & $3.0 \pm 0.7$ & $\mathbf{3 . 8} \pm \mathbf{2 . 1}$ & $8.0 \pm 2.5$ & $10.8 \pm 1.3$ & $12.9 \pm 1.8$ \\
\hline Pileostegia & $\mathbf{1 . 8} \pm \mathbf{0 . 2}$ & $3.1 \pm 0.9$ & $\mathbf{4 . 8} \pm \mathbf{2 . 1}$ & $7.6 \pm 2.1$ & $11.1 \pm 1.3$ & $12.6 \pm 1.7$ \\
\hline p value & $<.001$ & 0.984 & $<.001$ & 0.978 & 0.165 & 0.101 \\
\hline LSD & 0.33 & 1.03 & 0.48 & 2.29 & 0.69 & 0.83 \\
\hline
\end{tabular}

*'Cold' days were when the mean ambient temperature between 05:00 and 07:00 at the UoR MO was $\leq 3^{\circ} \mathrm{C}$. 'Warm' days were when the mean ambient temperature between 05:00 and 07:00 at the UoR MO was $>9{ }^{\circ} \mathrm{C}$. Unheated $(\mathrm{UH})$, heated $(\mathrm{H})$. Unheated and heated days occurred on different days. Numbers in bold indicate that those values are significantly different from others in the same column (ANOVA, $p<0.05)$.

\section{Discussion}

In our experiment Hedera and the other tested species reduced peak internal and external building temperatures by at least $1{ }^{\circ} \mathrm{C}$ in summer, due to cooling by shading and evapotranspiration. This was a similar reduction in temperature to the findings of Cameron et al. (2014) and Perini et al. (2011a). Furthermore, all tested species displayed an ability to stabilise temperature, reducing the temperature range, internally and externally by at least $2{ }^{\circ} \mathrm{C}$ in summer, which was similar to the stabilisation effects found by Sternberg et al. (2011).

The findings concerning $\mathrm{RH}$ and potential insulating properties of Hedera were variable. During the afternoons (in summer) the external RH mostly appeared to be higher behind Hedera foliage. In summer this effect appears to largely result from evapotranspiration. Impacts on RH were more pronounced for Hedera (an increase of at least 9\% during the summer afternoons), than the other tested plant species (which produced smaller impacts on RH around the model 'buildings'). The effect of vegetation on the internal $\mathrm{RH}$ depends largely on the climatic circumstances; in summer (during both mornings and afternoons), the RH increased inside the 'buildings' of most tested species (though Pileostegia produced the least increase). The effect of the Hedera-covering on internal RH in winter was less pronounced, and is likely to be due to interactions between the heaters heating the air (and reducing the relative humidity, if not the absolute humidity). In winter, when the wall coverage by leaves was $89 \pm 6 \%$, the $\mathrm{RH}$ inside the Hedera-covered buildings was lower than the RH measured inside the bare 'buildings' during both mornings and afternoons. This may be due to a combination of 
slightly warmer temperatures inside the Hedera-covered buildings and slightly reduced external RH behind the Hedera foliage, though this requires further research to elucidate the causes.

Interestingly, there was a mostly non-significant trend for the external $\mathrm{RH}$ measured behind the foliage of all species to be lower than that of the bare buildings during the nights/mornings throughout both seasons, which may indicate that the slight increase in air temperature due to the insulation effects of the foliage was sufficient to maintain the lower RH. No comparable studies have been found within the literature; similar effects are reported (Miller et al., 2007, Ottelé, 2011), but as they were not the focus of the studies, an explanation for the effect was not given.

The increased $\mathrm{RH}$ measured behind Hedera foliage compared to the bare buildings during summer afternoons (i.e. 9-11\% in our experiment) is not, however, expected to particularly represent an issue practically for the following reasons. Firstly, Hedera's protective effect from driving rain may counteract some of the impact on external RH derived from its tendency to trap water vapour. Moreover, it is believed that a well-constructed and maintained building (including cavity walls and modern cement work) would prove resistant to internal increases in $\mathrm{RH}$, though this requires further research. Therefore, Hedera-based schemes, and direct greening in general, could prove very successful where installed with consideration of building integrity and the local climate. For example, it might prove beneficial to green walls particularly affected by driving rain, and leverage the benefits of precipitation interception by foliage.

Furthermore, as identified by Perini et al. (2011a) and Bolton et al. (2014), the insulation effects of direct greening are minimal at intermediate temperatures, though they do improve as temperatures reach extremes. In winter, this may be a side effect of the shading provided by plants used in greening, which reduces temperatures (especially at the southern aspect) by inhibiting solar gains, as was also found by in a simulation of vertical greening (Carlos, 2015). It may, therefore be advisable to prune evergreen species (such as Hedera) in autumn to avoid this problem, or use a deciduous species such as Parthenocissus (or other deciduous climbing species suitable to the site). Pruning may also improve insulation against wind and rain by increasing foliage density in the following year (McAllister and Marshall, 2017), through the removal of apical dominance and encouragement of lateral branching.

In addition, the insulating effects found externally during the summer mornings (up to $2.6^{\circ} \mathrm{C}$ warmer for the Hedera-covering) did not appear to translate to the internal environment. It is believed that this effect, in the case of Hedera, may be due to a lag in the heat transfer between the building envelope and the internal environment. Therefore, the temperature increase behind the foliage derived from night-time insulation does not translate to the internal environment until the daytime, 
when it is overwhelmed by the much larger increases from summer solar gains. It is beneficial that the presence of Hedera does not increase the internal building temperature at night during the summer, as this is a cause of thermal discomfort during hot summers and in cities suffering from the urban heat island effect. This is complemented by a positive effect during the warmest hours of the day, when the internal temperatures of Hedera-covered buildings can be $7^{\circ} \mathrm{C}$ lower than bare buildings.

In winter, however, the same insulation effects and resulting increase in external temperature did translate to an increase in internal temperatures [by up to $2{ }^{\circ} \mathrm{C}$ (in the mornings) for Hedera-covering, which was similar to that reported by Bolton et al. (2014)]. This may be because there is relatively little contribution from solar gains during this period and external ambient temperatures are lower, which would increase heat transfer to the environment.

The findings have shown that wall greening cab be an effective tool (as part of a multi-approach solution) to some problems associated with building climate control. Anecdotally, space heating and air conditioning tend to be more expensive to operate than dehumidifiers, therefore, it may be sensible to utilise the benefits of plants for summer cooling and winter insulation, even if RH is slightly increased at times. As Hedera is an evergreen species resilient to pollution, drought, poor soil conditions (Steubing et al., 1989, Dunnett and Kingsbury, 2008, Sternberg et al., 2010, McAllister and Marshall, 2017), it is therefore proposed that it would, if properly maintained, be well suited to any greening scheme that requires year-round cover. By comparison, the deciduous Parthenocissus might be best suited for situations where cover is only required during summer months or would be unhelpful in winter. An example would be on a south facing wall on a building where solar gains during winter, uninhibited by leaves, would be beneficial, as would summer cooling from the shading provided by foliage. Pileostegia by comparison is a slower-growing alternative, of smaller stature, that provides some of the benefits of Hedera, but without the negative associations, and therefore may be considered an addition to the 'toolkit' for smaller greening schemes. Therefore, with appropriate precautions, the historical fears concerning the effect of Hedera on structure RH could be overcome, and other evergreens such as Pileostegia could be used as an alternative.

The model buildings used may not incorporate the complex structural geometry of buildings, but this simplified approach enables initial insights into sensitivity analysis, bypassing waiting for several years to measure actual details of full-scale greening on houses.

\subsection{Limitations of the work}

In setting up our experiment, we have constructed model mini 'buildings' which were mortared, had ground and 'roof' insulation, but only represented one layer of skin. The use of model 'buildings' to 
simulate full-scale buildings and how they may be impacted by greening will have its limitations in replicating the full-scale systems. We believe, however, that the results presented in this research are valuable as an initial insight into possible impact of different plant species and can be further developed to enhance the understanding of other varying parameters. The model buildings are, in our mind, adequate for the sensitivity analysis of building designs.

On the other hand, green façade plants were allowed to grow as if they were on a 'real size' building, without crown thinning or reduction. While this approach could have thus overestimated the impact of planting on a real-size building's interior, this is particularly encouraging in thus suggesting that any negative impacts (e.g. higher RH in model building) would therefore be very small in the full scale building. The measurements on the external skin of the building however, directly behind foliage, should not be influenced by the building scale but instead the transmission parameters which are impacted on by the foliage thickness.

We believe that the value of our approach comes from replicated measurements of a number of model buildings, three for each treatment. This provides us with a 'sense of direction' of how plant species differ when applied as a form of building greening, using structurally different plants - e.g. what's the impact of plants shedding leaves during the winter, rather than solely absolute values in terms of number of degrees of cooling/warming or humidity impacts. 


\section{Acknowledgements}

This work was financially supported by the Royal Horticultural Society (RHS), Sutton Griffin Architects, and Engineering and Physical Sciences Research Council (ESPRC) [grant EP/G037787/1] to the Technologies for Sustainable Built Environments Centre (TSBE) at University of Reading. The authors would like to thank Roderick Griffin, Chris Trickey, Val Jasper, Tobias Lane, James Hadley and Matthew Richardson for their expert technical help. 


\section{References}

ASHRAE (2013). ANSI/ASHRAE Standard 62.1-2013 Ventilation for acceptable indoor air quality. Atlanta, GA: American Society of Heating, Refrigerating and Air-conditioning Engineers Inc. (ASHRAE)

Bernstein, L., Huq, S., Matsuno , T., Palutikof, J., Rosenzweig, C., Sugiyama, T., Bosch, P., Karoly, D., Menne, B., Parry, M., Rusticucci, M., Swart, R., Canziani, O., Kattsov, V., Metz, B., Qin, D., Schneider, S., Tirpak, D., Chen, Z., Kundzewicz, Z., Mirza, M., Ravindranath, N., Sokona, Y., Vogel, C., Christ, R., Liu, J., Nicholls, N., Reisinger, A., Solomon, S., Yohe, G., Davidson, O., Lohmann, U., Nurse, L., Ren, J., Stott, P., Hare, W., Manning, M., Pachauri, R., Riahi, K., Stouffer, R. \& Barker, T. (2007). Climate Change 2007 : Synthesis Report. An Assessment of the Intergovernmental Panel on Climate Change. Valencia: Intergovernmental Panel on Climate Change.

Blanuša, T., Vaz Monteiro, M. M., Fantozzi, F., Vysini, E., Li, Y. \& Cameron, R. W. F. (2013). Alternatives to sedum on green roofs: Can broad leaf perennial plants offer better 'cooling service'? Building and Environment, 59, 99-106.

Bolton, C., Rahman, M. A., Armson, D. \& Ennos, A. R. (2014). Effectiveness of an ivy covering at insulating a building against the cold in Manchester, U.K: A preliminary investigation. Building and Environment, 80, 32-35.

BRE (Building Research Establishment), Construction Research Communications Ltd \& Building Research Establishment Executive Agency (1996). Bird, Bee and Plant Damage to Buildings. London: Construction Research Communications.

Cameron, R. W. F., Taylor, J. E. \& Emmett, M. R. (2014). What's 'cool' in the world of green façades? How plant choice influences the cooling properties of green walls. Building and Environment, 73, 198-207.

Cameron, R. W. F., Taylor, J. E. \& Emmett, M. R. (2015). A Hedera green façade - Energy performance and saving under different maritime-temperate, winter weather conditions. Building and Environment, 92, 111-121.

Cantuaria, G. A. C. (2000). A comparative study of the thermal performance of vegetation on building surfaces. In: Steemers, K., Yannas, S. \& Organisation, I. P. (eds.) Architecture, City, Environment: Proceedings of PLEA 2000: July 2000, Cambridge. London: James \& James.

Carlos, J. S. (2015). Simulation assessment of living wall thermal performance in winter in the climate of Portugal. Building Simulation, 8, 3-11.

D'Ayala, D. \& Aktas, Y. D. (2016). Moisture dynamics in the masonry fabric of historic buildings subjected to wind-driven rain and flooding. Building and Environment, 104, 208-220.

Di, H. F. \& Wang, D. N. (1999). Cooling effect of ivy on a wall. Experimental Heat Transfer: A Journal of Thermal Energy Generation, Transport, Storage, and Conversion, 12, 235-245.

Djedjig, R., Belarbi, R. \& Bozonnet, E. (2017). Experimental study of green walls impacts on buildings in summer and winter under an oceanic climate. Energy and Buildings, 150, 403-411.

Douglas, J. \& Noy, E. A. (2011). Building Surveys and Reports. $4^{\text {th }}$ ed. Chichester: Wiley-Blackwell.

Dunnett, N. \& Kingsbury, N. (2008). Planting green roofs and living walls. Portland, OR: Timber Press.

EPA. (2017). Global greenhouse gas emissions data. URL: https://www.epa.gov/ghgemissions/globalgreenhouse-gas-emissions-data: [20/04/2018].

Eumorfopoulou, E. A. \& Kontoleon, K. J. (2009). Experimental approach to the contribution of plantcovered walls to the thermal behaviour of building envelopes. Building and Environment, 44, 1024-1038.

Feitosa RC, Wilkinson SJ (2018) Attenuating heat stress through green roof and green wall retrofit. Building and Environment 140:11-22

Green, D. W. \& Perry, R. H. eds. (2007). Perry's chemical engineers' handbook. $8^{\text {th }}$ ed. New York, NY: McGraw-Hill Education. 
Hamilton, I. G., Steadman, P. J., Bruhns, H., Summerfield, A. J. \& Lowe, R. (2013). Energy efficiency in the British housing stock: Energy demand and the Homes Energy Efficiency Database. Energy Policy, 60, 462-480.

Hoelscher, M.-T., Nehls, T., Jänicke, B. \& Wessolek, G. (2016). Quantifying cooling effects of façade greening: Shading, transpiration and insulation. Energy and Buildings, 114, 283-290.

Hoyano, A. (1988). Climatological uses of plants for solar control and the effects on the thermal environment of a building. Energy and Buildings, 11, 181-199.

Ip, K., Lam, M. \& Miller, A. (2010). Shading performance of a vertical deciduous climbing plant canopy. Building and Environment, 45, 81-88.

Ip, K., Marta, L. \& Miller, A. (2004). Bioshaders for sustainable buildings. In: International Council for Research and Innovation in Building and Construction. CIB 2004 World Building Congress, Toronto, Canada, 1-7 May 2004. s.I.: s.n.

Karagiozis, A. N., Salonvaara, M., Holm, A. \& Kuenzel, H. (2003). Influence of wind-driven rain data on hygrothermal performance. In: IBPSA. Building simulation 2003. Proceedings of the eighth international IBPSA conference. Eindhoven, Netherlands, 11-14 August 2003.

URL: http://www.ibpsa.org/proceedings/BS2003/BS03_0627_634.pdf: [23/02/2019]

Köhler, M. (1993). Fassaden- und Dachbegrünung (Façade and roof greening). Stuttgart: Ulmer Fachbuch.

Koyama, T., Yoshinaga, M., Hayashi, H., Maeda, K.-i. \& Yamauchi, A. (2013). Identification of key plant traits contributing to the cooling effects of green façades using freestanding walls. Building and Environment, 66, 96-103.

Kronvall, J. \& Rosenlund, H. (2014). Hygro-thermal and energy related performance of vertical greening on exterior walls - A field measurement study. In: NSB, 10th Nordic Symposium on Building Physics. Lund, Sweden, 15-19 June 2014. URL:

https://www.lunduniversity.lu.se/lup/publication/eadb6ef8-878a-4922-9dbf-384d29ac8b23: [23/02/2019]

Kumaraperumal, K. A. N. (2009). Modelling and measurement of wind-driven rain on building facades. PhD Thesis, Glasgow Caledonian University.

Matheus, C., Caetano, F. D. N., Morelli, D. D. d. O. \& Labaki, L. C. (2016). Desempenho térmico de envoltórias vegetadas em edificações no sudeste brasileiro (Thermal performance of vegetated envelopes in buildings in southeastern Brazil). Ambiente Construído, 16, 71-81.

McAllister, H. \& Marshall, R. (2017). Hedera: the complete guide. London: Royal Horticultural Society (RHS).

Miller, A., Shaw, K. \& Lam, M. (2007). Case study report - Vegetation on building facades: "Bioshader". Brighton: University of Brighton.

Muckley, W. J. (1886). Ivy a cure for damp walls. The Garden: An Illustrated Weekly Journal of Horticulture in All Its Branches. 29, 163 (column 2).

URL: https://www.biodiversitylibrary.org/item/82670\#page/193/mode/1up: [25/02/2019]

Ottelé, M. (2011). The Green Building Envelope Vertical Greening. PhD Thesis, Technische Universiteit Delft, Netherlands

Ottelé, M. \& Perini, K. (2017). Comparative experimental approach to investigate the thermal behaviour of vertical greened façades of buildings. Ecological Engineering, 108, 152-161.

Pérez, G., Rincón, L., Vila, A., González, J. M. \& Cabeza, L. F. (2011a). Behaviour of green facades in Mediterranean continental climate. Energy Conversion and Management, 52, 1861-1867.

Pérez, G., Rincón, L., Vila, A., González, J. M. \& Cabeza, L. F. (2011b). Green vertical systems for buildings as passive systems for energy savings. Applied Energy, 88, 4854-4859.

Perini, K., Magliocco, A. \& Giulini, S. (2017). Vertical greening systems evaporation measurements: Does plant species influence cooling performances? International Journal of Ventilation, 16, 152-160. 
Perini, K., Ottelé, M., Fraaij, A. L. A., Haas, E. M. \& Raiteri, R. (2011a). Vertical greening systems and the effect on air flow and temperature on the building envelope. Building and Environment, 46, 2287-2294.

Perini, K., Ottelé, M., Haas, E. M. \& Raiteri, R. (2011b). Greening the building envelope, façade greening and living wall systems. Open Journal of Ecology, 01, 1-8.

Ran, J. and Tang, M., 2018. Passive cooling of the green roofs combined with night-time ventilation and walls insulation in hot and humid regions. Sustainable cities and society, 38, pp.466-475.

Rath, J., KießI, K. \& Gertis, K. (1989). Auswirkungen von Fassadenbegrünungen auf den Wärme- und Feuchtehaushalt von Außenwänden und Schadensrisiko (Effects of facade greening on the heat and moisture balance of exterior walls and damage risk). Stuttgart: Fraunhofer IRBVerlag.

Sternberg, T., Ashbee, J., Cathersides, A., Thomas, R., Turner, C., Viles, H. \& White, A. (2010). Ivy on walls: Seminar report. s.I.: English Heritage. URL: https://www.geog.ox.ac.uk/research /landscape/rubble/ivy/ivy-report.pdf: [27/02/2019]

Sternberg, T., Viles, H. \& Cathersides, A. (2011). Evaluating the role of ivy (Hedera helix) in moderating wall surface microclimates and contributing to the bioprotection of historic buildings. Building and Environment, 46, 293-297.

Steubing, L., Fangmeier, A., Both, R. \& Frankenfeld, M. (1989). Effects of $\mathrm{SO}_{2}, \mathrm{NO}_{2}$, and $\mathrm{O}_{3}$ on population development and morphological and physiological parameters of native herb layer species in a beech forest. Environmental Pollution, 58, 281-302.

Susorova, I., Angulo, M., Bahrami, P. \& Brent, S. (2013). A model of vegetated exterior facades for evaluation of wall thermal performance. Building and Environment, 67, 1-13.

Taddyforde, K. K., Hobday, E., Rust, J., Cruden, W., Watney, H. \& Mervyn (1877). Gardeners' Chronicle A Weekly Illustrated Journal of Horticulture and Allied Subjects, Volume VII. London: Haymarket Publishing.

Thomsit-Ireland, F. (2019). Overcoming the barriers to green walls in urban areas of the UK. EngD Thesis, University of Reading.

Vox G, Blanco I, Schettini E (2018) Green façades to control wall surface temperature in buildings. Building and Environment 129:154-166

WHO (2009). WHO Guidelines for Indoor Air Quality: Dampness and Mould. Copenhagen: World Health Organization.

Widiastuti, R., Caesarendra, W., Prianto, E. and Budi, W.S., 2018. Study on the leaves densities as parameter for effectiveness of energy transfer on the green facade. Buildings, 8(10), 138

Wong, N. H., Kwang Tan, A. Y., Chen, Y., Sekar, K., Tan, P. Y., Chan, D., Chiang, K. \& Wong, N. C. (2010). Thermal evaluation of vertical greenery systems for building walls. Building and Environment, 45, 663-672.

Zhang, L., Deng, Z., Liang, L., Zhang, Y., Meng, Q., Wang, J. and Santamouris, M., 2019. Thermal behavior of a vertical green facade and its impact on the indoor and outdoor thermal environment. Energy and Buildings, 204, p.109502.

Zhang, X. L., Li, K. L. \& Skitmore, M. (2013). Creeping insulation - Hong Kong green wall. International Journal of Environmental and Ecological Engineering, 7, 729-734. 


\section{Appendix A}

Sensor layout for summer 2015 (Figure A.1) and winter 2016 (Figure A.2) experiments.

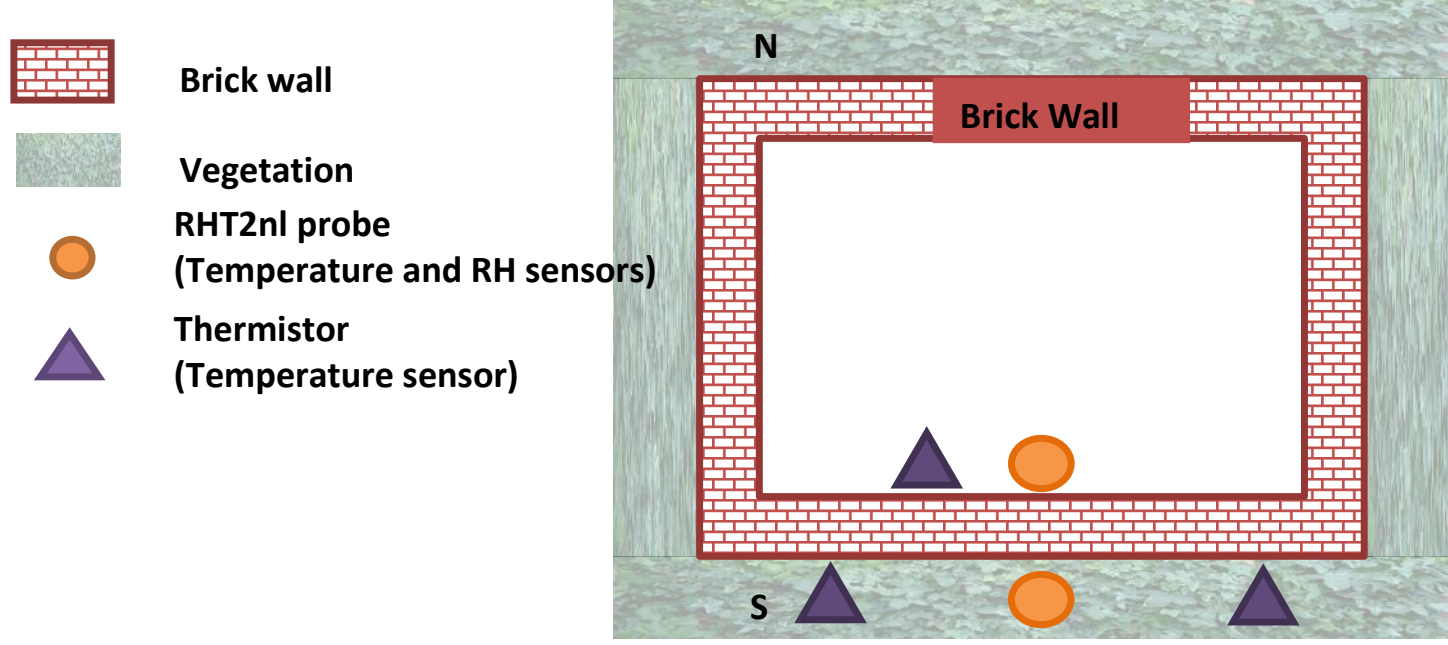

Figure A.1 Sensor layout during summer 2015 , not to scale

Brick wall
Vegetation
RHT2nl probe
(Temperature and RH sensors)
Immersion heater

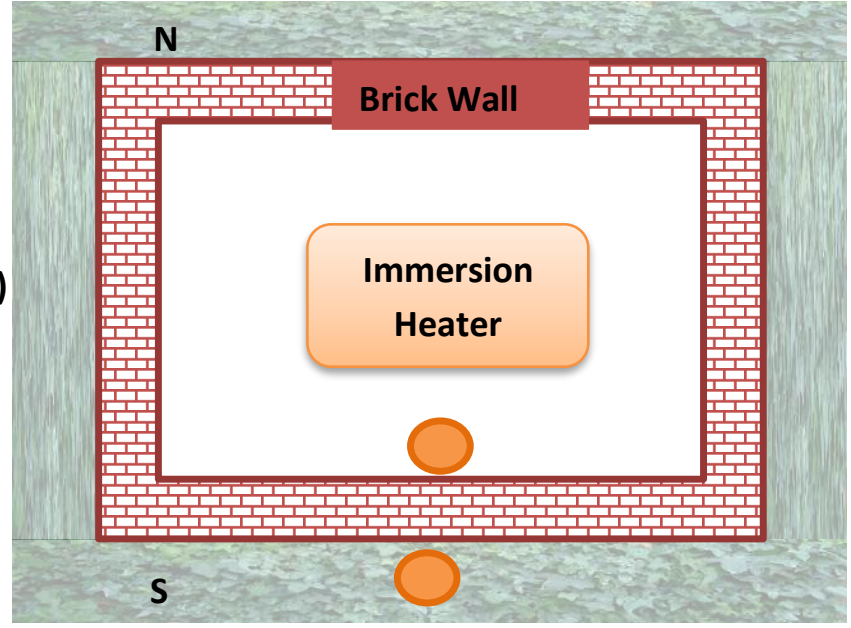

Figure A.2 Sensor layout during winter 2016, not to scale 